\title{
First report of powdery mildew caused by Podosphaera xanthii on Cucurbita maxima in Korea
}

\author{
In-Young Choi ${ }^{1} \cdot$ Young-Joon Choi ${ }^{2} \cdot$ Hyeon-Dong Shin $^{3}$
}

Received: 16 September 2019 / Accepted: 2 December 2019 /Published online: 24 December 2019

(C) Società Italiana di Patologia Vegetale (S.I.Pa.V.) 2019

Keywords Cucurbita maxima $\cdot$ ITS $\cdot$ Podosphaera xanthii $\cdot$ Powdery mildew

Cucurbita maxima Duchesne, commonly called winter squash, is an annual vining-type plant in the family Cucurbitaceae, that originates in South America. It is cultivated for edible fruits or ornamental colourful fruits in many countries. During August 2013, C. maxima plants showing powdery mildew symptoms were observed in Korea. Circular to irregular colonies formed white patches on both sides of the leaves, petioles and young stems. As the disease progressed, white mycelium covered the entire leaves, causing leaf distortion and necrosis. No symptoms were found on fruits and inflorescence. Hyphae were flexuous to straight, branched, septate, and 5 to $7 \mu \mathrm{m}$ wide. Appressoria on the mycelium were nipple-shaped or nearly absent. Conidiophores were straight, 120 to $220 \times 11$ to $13 \mu \mathrm{m}$, producing 2 to 5 immature conidia in chains with a crenate outline. Conidiophore foot-cells were cylindric with slightly swollen base and 40 to $75 \mu \mathrm{m}$ long. Conidia were ellipsoid-ovoid to barrel-shaped, 30 to $40 \times 18$ to $22 \mu \mathrm{m}$ in size, with a length/width ratio of 1.4 to 2.0 , and contained distinct fibrosin bodies. Conidia produced simple to forked germ tubes laterally. No chasmothecia were found during the growing seasons. The morphological characteristics were consistent with those of Podosphaera xanthii (Castagne) U. Braun \& Shishkoff (Braun and Cook 2012). To help morphological identification, the internal transcribed spacer (ITS) region of isolate KUS-F27525 was amplified using primers ITS5/P3, and sequenced directly. A 590 bp fragment was obtained and

Hyeon-Dong Shin

hdshin@korea.ac.kr

1 Department of Agricultural Biology, Chonbuk National University, Jeonju 54896, South Korea

2 Department of Biology, Kunsan National University, Gunsan 54150, South Korea

3 Division of Environmental Science and Ecological Engineering, Korea University, Seoul 02841, South Korea the sequence was deposited in GenBank (accession No. KX061106). A GenBank BLAST search of the Korean isolate showed $>99 \%$ similarity $(589 / 590)$ with the sequence of different $P$. xanthii isolates (AB462800, KJ472787, KP120970, KP120971, KP120972, etc.). Powdery mildew of C. maxima caused by Podosphaera species has been recorded globally but not in Korea (Farr and Rossman 2019). Previously, C. moschata and C. pepo var. oleifera were reported to be infected with $P$. xanthii in Korea, therefore, this is the first report of powdery mildew caused by $P$. xanthii on $C$. maxima in Korea. Three voucher specimens have been deposited in the Korea University Herbarium (Accession Nos. KUS-F27525, F27901, F28672).

Acknowledgements This paper was supported by research funds for newly appointed professors of Chonbuk National University in 2019 to IYC.

\section{References}

Braun U, Cook, RTA (2012) Taxonomic manual of the Erysiphales (Powdery Mildews). CBS Biodiversity Series No. 11. CBS, Utrecht, The Netherlands

Farr DF, Rossman AY (2019) Fungal databases, syst. Mycol. Microbiol. Lab., Online publication. ARS, USDA. Retrieved September 16, 2019

Publisher's note Springer Nature remains neutral with regard to jurisdictional claims in published maps and institutional affiliations. 